\title{
Pom34 mRNA is the Only Target of the Sesa Network
}

\author{
Pom34 mRNA'sı Sesa Ağının Tek Hedefidir
}

\author{
Research Article
}

Bengü Ergüden

Gebze Technical University, Department of Bioengineering, Turkey.

\section{A B S TR AC T}

$M^{P S 2}$ is an essential gene required for the insertion of Saccharomyces cerevisiae centrosome into the nuc W lear membrane. Upon its deletion, cell cycle is stopped and the cell dies. Recently, we reported that SESA network can suppress essential role of MPS2. Detailed analysis showed that SESA is a system which suppresses centrosome duplication defects by inhibiting the translation of a subset of mRNAs selectively. In this study, we report the results of a genome-wide deletion screen which unearthed Pom34 mRNA as the only target of the SESA network.

\section{Key Words}

Saccharomyces cerevisiae, centrosome duplication, Pom34, SESA network.

\section{öz}

\begin{abstract}
Saccharomyces cerevisiae sentrozomunun çekirdek zarına yerleşmesi için gerekli olan MPS2, bir elzem gen$\int$ dir. Bu genin silinmesi, hücre döngüsünü durdurur ve hücre ölümüne yol açar. Bir süre önce, SESA ağının MPS2 temel fonksiyonunu baskılayabildiğini gösterdik. Ayrıntılı analizler SESA sisteminin, maya sentrozomu eşlenmesi hatalarını gidermek için bir kısım mRNAnın translasyonunu seçici olarak baskıladığını ortaya koymuştur. Bu çalışmada ise genom ölçeğinde yaptığımız tarama ile Pom34 mRNAsının SESA ağnın tek hedefi olduğunu ortaya çıkardık.
\end{abstract}

\section{Anahtar Kelimeler}

Saccharomyces cerevisiae, sentrozom eşlenmesi, Pom34, SESA ağı.

Article History: Received: Mar 06, 2017; Revised: May 21, 2017; Accepted: Sep 11, 2017; Available Online: Dec $25,2017$. DOI: $10.15671 /$ HJBC.2018.195

Correspondence to: B. Ergüden, Gebze Technical University, Department of Bioengineering, Turkey. 


\section{INTRODUCTION}

The he Saccharomyces cerevisiae nuclear membrane is part of a complex nuclear envelope environment also containing chromatin, integral and peripheral membrane proteins, and large structures such as nuclear pore complexes (NPCs) and the yeast centrosome (spindle pole body, SPB) [1]. Both NPCs and SPBs are composed primarily of soluble proteins that partially assemble into subcomplexes in the nucleus or cytoplasm and must insert in the core inside the membrane where inner and outer nuclear membranes join [2]. But the specific mechanism of how NPC and SPCs are inserted into the yeast nuclear envelope is not known. Specific integral membrane proteins interact with soluble components of the NPC and SPB and are thought to anchor the complexes in the nuclear envelope. MPS2 is one of the integral membrane proteins that are required for the insertion of SPB into the nuclear envelope [3].

MPS2 is an essential gene required for the insertion of SPB into the nuclear membrane. Upon its deletion, cell cycle is stopped and the cell dies $[3,4]$. Recently, we reported that Smy2 can suppress essential role of MPS2 and co-operates with Eap1, Scp160, Asc1 for this task and we gave the name SESA network (Smy2, Eap1, Scp160, Asc1) to the system consisting of these four proteins [5]. Detailed analysis showed that the SESA system is part of a mechanism which regulates translation of a subset of mRNAs. Pom34 mRNA was discovered as one of the target mRNAs. It encodes an integral membrane protein which is important for the NPC biogenesis, together with other NPC components Pom152 and Ndc1 [6-10]. Thus, SESA, is a system which suppresses SPB duplication defects by inhibiting the translation of a subset of mRNAs including Pom34 [5].

Although many important points regarding SESA network have been discovered, many others remain unsolved. Most importantly target mRNAs other than Pom34 remained obscure before this study [5]. In this work, we report the results of a genome-wide screen performed to uncover new targets of the SESA network by transforming SESA active cells with mTn3-lacZ/LEU2 Snyder deletion-insertion library.

\section{MATERIALS and METHODS}

\section{Transformation of MPS2 2 pR316-MPS2 Cells with Snyder Library}

mTn3-lacZ/LEU2 Snyder library DNA [11] was digested with Notl. $50 \mathrm{ml}$ overnight culture of MPS2 $\triangle$ pRS316-MPS2 cells were spun down, washed with water and resuspended in $350 \mu \mathrm{L}$ LiSorb. $50 \mu \mathrm{L}$ carrier DNA was added and $50 \mu \mathrm{L}$ yeast cells were transformed with $5 \mu \mathrm{L}$ of digested library DNA. The tranformants were spun down, resuspended in $1 \mathrm{ml}$ YPDA and recovered for $5 \mathrm{~h}$ at $23 \mathrm{C}$. After recovery the transformants are plated out on SC-Leu plates and incubated for 2-3 days so that each plate has around 200 isolated colonies. In the end the number of colonies must reach $3000-4000$ colonies for each pool and 30,000 colonies in total.

The colonies were replica plated on SC+5-FOA plates and the DNA of the yeast strains which grow on $\mathrm{SC}+5-\mathrm{FOA}$ plates were isolated.

\section{Primers}

S1- and S2-primers were used for the deletion of yeast genes. S2- and S3-primer pairs were suitable for C-terminal epitope tagging of yeast genes. S1-, S2- and S3-primers for the amplification of pYM modules [12] were constructed as follows:

All S-primers contain chromosomal sequences for homologous recombination followed by nucleotide sequences for the amplification of the pYM modules. S1 (forward) primers contain $45-55$ bases of the gene-specific sequence upstream from the START codon including the START codon plus 5'-CGTACGCTGCAGGTCGAC-3' for the amplification of the PYM modules. S2 (reverse) primers contain 45-55 bases of the gene-specific sequence downstream from STOP including the STOP codon plus 5'-ATCGATGAATTCGAGCTCG-3' sequence for the amplification of the pYM modules. S3 (forward) primers are identical to the 45-55 bases of the gene-specific sequence upstream of the STOP codon not including the STOP codon and contain the 5'-CGTACGCTGCAGGTCGAC-3' sequence for amplification of the module.

\section{Transformation of Yeast Cells}

50 I of yeast competent cells per transformation were thawed at room temperature. DNA was 
added to cells followed by 300 I LiPEG and briefly vortexed to mix. Cells were then incubated at room temperature for $20 \mathrm{~min}$. 30 I DMSO was then added and mixed immediately by vortexing. The transformations were then heat shocked in a water bath at $42^{\circ} \mathrm{C}$ for $15 \mathrm{~min}$ (10 min if temperature sensitive strain being used). Cells were pelleted at 3,200 rpm for $3 \mathrm{~min}$, resuspended in 200 I PBS and plated onto selective plates for 2-3 day incubation at $30^{\circ} \mathrm{C}\left(23^{\circ} \mathrm{C}\right.$ for temperature sensitive strains).

\section{Antibodies and Immunoblotting}

Yeast extracts were prepared using alkaline lysis and TCA precipitation [5]. To detect proteins by immunoblotting procedures, blocked membranes (Protean, Schleicher \&Schuell) were incubated for $2 \mathrm{~h}$ at $20^{\circ} \mathrm{C}$ or overnight at $4^{\circ} \mathrm{C}$ with antibodies diluted in blocking buffer (PBS, $0.2 \%$ Tween $20,5 \%$ dry milk powder) followed by peroxidase-conjugated secondary antibodies [Sigma] and detection with ECL (Roche Molecular Biochemicals). Anti-Tub2 antibody (yeast b-tubulin, GSTTub2436-457) was prepared in rabbits against purified recombinant peptides [5]. Monoclonal mouse anti-HA (12CA5) antibody was from Roche Molecular Biochemicals.

\section{RESULTS and DISCUSSION}

\section{Genome-wide Deletion Screen to Unearth Possible Targets of SESA Network}

Snyder mTn3-lacZ/LEU2 yeast DNA library screen is based on insertion-deletion mutation. Yeast DNA library was incorporated into a bacterial vector and later underwent transposone mutation in E. coli [11]. When library DNA is isolated and cut with Notl enzyme, yeast genes containing mTn3lacZ/LEU2 fragments are obtained. Yeast cells having leu2 genetic background are transformed with the cut library DNA to achieve insertion-deletion mutation in cells. Here a randomly targeted gene is deleted.

There are two important aspects of this strategy. First, the mutation is an insertion-deletion mutation. Random mutations which target essential genes are lethal, thus only non-lethal genes are obtained in this mutation. Second, the insertion occurred during the mutation also serves to tag the deleted gene. With this in hand, the deleted gene that is responsible for the observed phenotype can be identified easily (Figure 1).

In cells, SESA network inhibits translation of its target gene. Thus it shows the same phenotype as the deletion of its target gene. For example, SESA inhibits translation of Pom34 mRNA. In SESA active cells due to the inhibition of translation of Pom34, MPS2 $\triangle$ cells can survive, while in SESA inactive cells MPS $2 \Delta$ cells do not survive. In the same way, MPS $2 \Delta$ cells in which Pom34 gene is deleted, namely MPS2 $\triangle$ Pom34 $\triangle$ double deletion strains are also viable. Consequently, genes whose deletion ensures survival of MPS2 $\triangle$ cells are the possible targets of the SESA network.

In order to determine possible targets of the SESA network, MPS2 $\triangle$ pRS316-MPS2 cells were transformed with NotI cut mTn3-lacZ/LEU2 library and selected on SC-Leu plates. Later they were replica plated on SC+5-FOA plates and the survivors were determined (Figure 2). All cells can survive in SC-Leu plates due to the pRS316-MPS2 plasmid. In contrast, since this plasmid is lost on SC+5-FOA plates, the cells have the MPS $2 \triangle$ genotype and thus most of them are inviable. The survivors have an additional deletion caused by the insertion of the mTn3-lacZ/LEU2 fragment and this deletion must be responsible for the survival of MPS2 $\triangle$ cells. This additional deletion is the possible target of the SESA network.

Yeast DNA of the survivors were isolated, digested with Rsal enzyme, amplified and sequenced as described in Figure 1 [11]. From the sequences of the neighboring DNA segments, deleted genes were determined as DEP1, FAA3, IPT1, OPI9, SEC66 and TRM1.

\section{Identification of Possible Targets of the SESA Network}

Genome-wide screen with Snyder mTn3-lacZ/ LEU2 library uncovered DEP1, FAA3, IPT1, OPI9, SEC66 and TRM1 as the possible SESA network targets. In order to test whether these are the real targets, each gene was deleted in MPS2 $\triangle$ pRS316-MPS2 cells and the resultant strains were tested for survival (Figure 3). On SC+5-FOA plates, pRS316-MPS2 plasmid was lost and survival of 


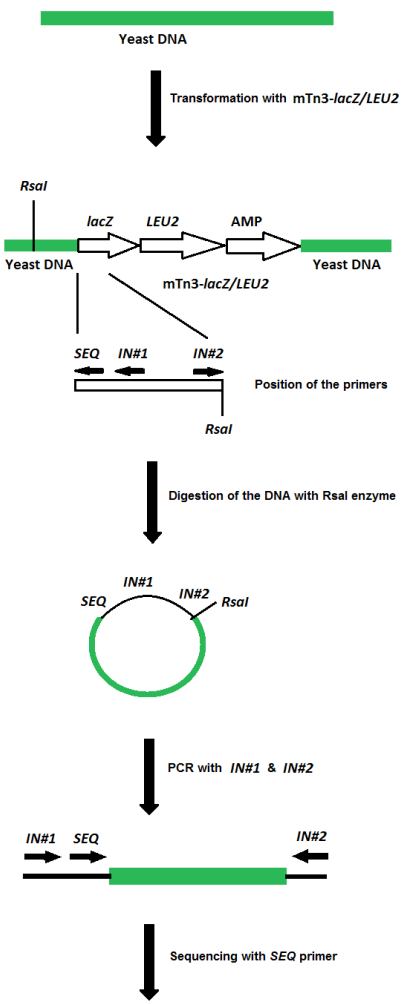

Figure 1. Deletion-insertion mutation in S. cerevisiae cells with mTn3-lacZ/LEU2 Snyder yeast library. MPS2 $\triangle$ pRS316MPS2 cells were transformed with NotI cut mTn3-lacZ/LEU2 library. Yeast DNA was isolated, digested with Rsal, amplified, and sequenced.

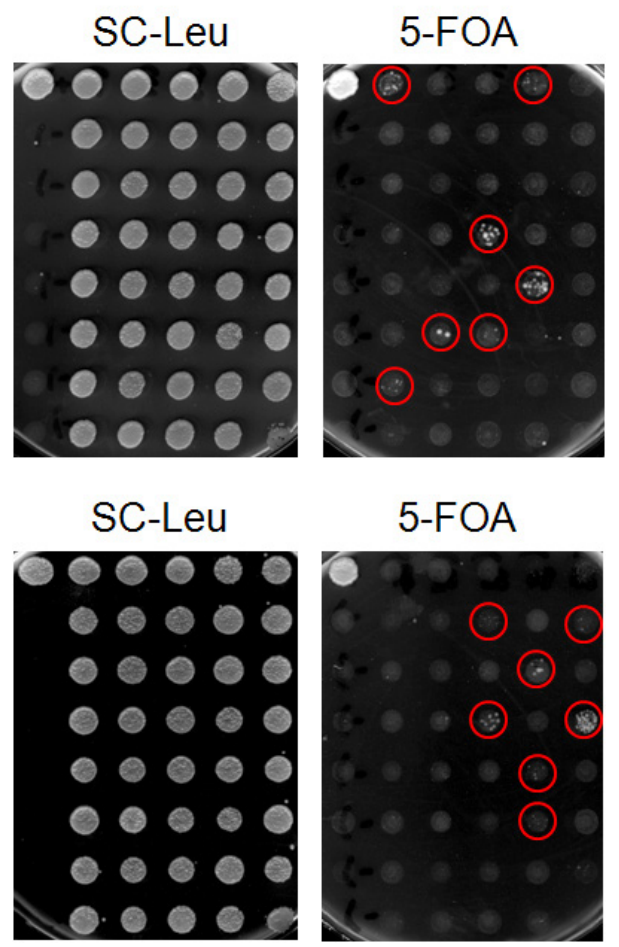

Figure 1. Survivors of the mTn3-lacZ/LEU2 Snyder DNA library transformants. MPS2 $\triangle$ pRS316-MPS2 cells were transformed with Notl cut mTn3-lacZ/LEU2 library and the transformants were grown on SC-Leu plates and SC+5-FOA plates. 

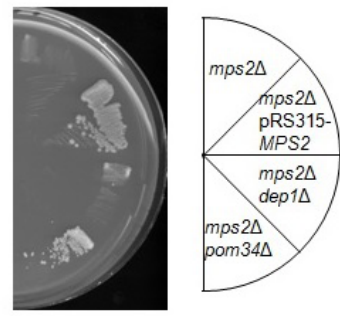

$5-F O A$
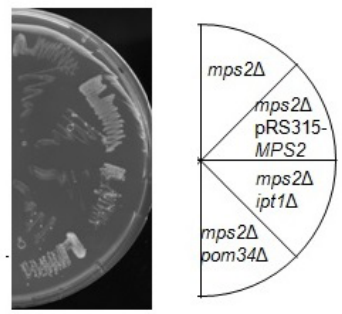

$5-F O A$
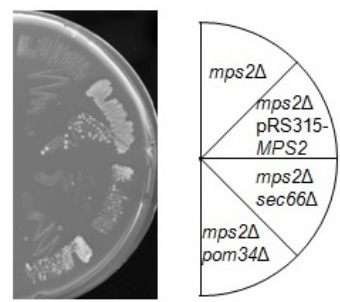

$5-F O A$
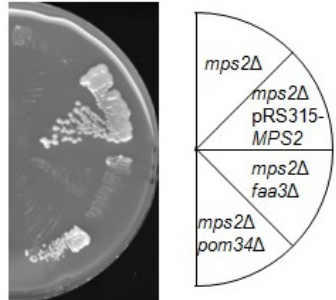

$5-F O A$
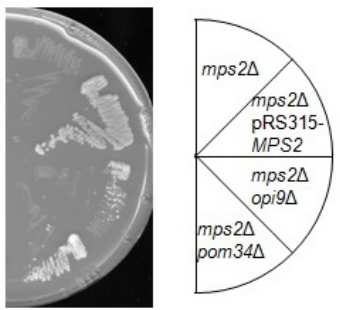

$5-F O A$
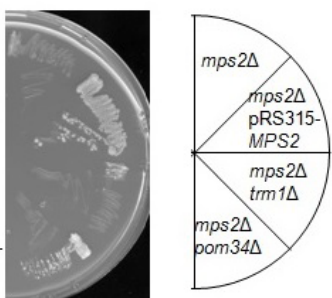

$5-F O A$

Figure 3. Effect of $d e p 1 \Delta$, faa $3 \Delta$, ipt $1 \Delta$, opi9 $\Delta, \sec 66 \Delta$ and $\operatorname{trm} 1 \Delta$ mutations on survival of MPS $2 \Delta$ cells. The indicated yeast strains were tested for growth on $\mathrm{SC}+5-\mathrm{FOA}$ plates at $23^{\circ} \mathrm{C}$ for three days.

the MPS2 $\triangle$ strains depend on the second deletion. As can be seen from the results, MPS2 $\Delta$ dep1 $1 \Delta$, MPS $2 \triangle$ faa $3 \Delta$ and MPS $2 \Delta \operatorname{trm} 1 \Delta$ double deletions are lethal. Deletion of DEP1, FAA3 and TRM1 did not ensure survival of the MPS $2 \triangle$ cells, they are the incorrect positives of the screen and are not targets of the SESA network.

On the other hand, MPS2 $\triangle$ ipt1 1 , MPS2 $\triangle$ opi9 $\triangle$ and MPS2 $2 \Delta$ sec66 6 cells are alive (Figure 3 ) [13]. Deletion of IPT1, OPI9 and SEC66 is responsible for survival of the MPS2 $\triangle$ cells and thus these gene products may be the targets of the SESA network.

The action of SESA network on its target gene is based on binding to the mRNA of its target gene and inhibiting its translation. Thus, the amount of target protein of the network in MPS2 $\triangle$ pRS425SMY2 cells is expected to be in lower amounts than in the wild type cells. In order to check whether the
mRNAs of IPT1, OPI9 and SEC66 are targeted by SESA, these genes are tagged with -6HA in MPS2 $\triangle$ pRS425-SMY2 cells by the method of Janke and coworkers [12], and the amounts of the corresponding proteins were determined by immunoblotting. As shown in Figure 4, the amount of Pom34 is reduced abruptly in MPS2 $\triangle$ pRS425-SMY2 cells compared to MPS2 $\triangle$ pRS315-MPS2 cells, due to the inhibition of its translation by the SESA network. In contrast Ipt1, Opi9 and Sec66 proteins are present in equal amounts in SESA active MPS2 $\triangle$ pRS425-SMY2 cells and SESA inactive MPS2 $\triangle \mathrm{pRS} 315-M P S 2$ cells; their translation is not inhibited by the effect of SESA. Consequently, IPT1, OPI9 and SEC66 mRNAs are not targets of the SESA network, Pom34 mRNA is the only detected target of the SESA network.

The correct separation of chromosomes during mitosis is necessary to prevent genetic instability and aneuploidy which causes cancer, and other dise- 


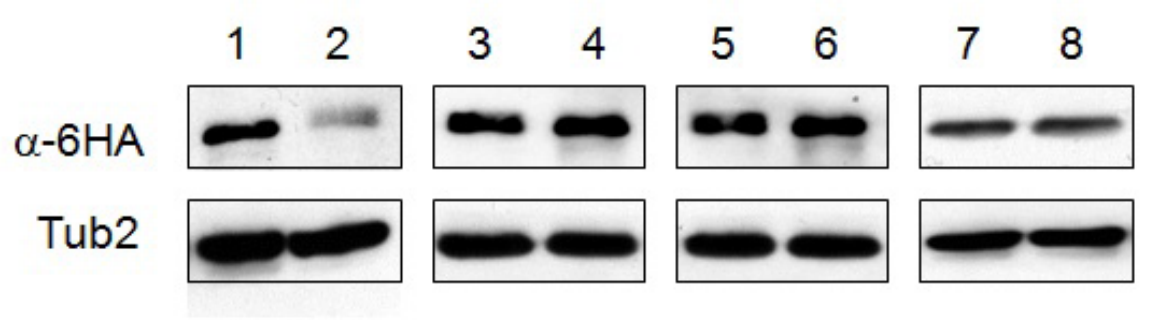

1 mps2 2 pRS315-MPS2 POM34-6HA
2 mps2 2 pRS425-SMY2 POM34-6HA
3 mps2 2 pRS315-MPS2 IPT1-6HA
4 mps2 2 pRS425-SMY2 IPT1-6HA
5 mps2 2 pRS315-MPS2 OPI9-6HA
6 mps2 2 pRS425-SMY2 OPI9-6HA
7 mps2 2 pRS315-MPS2 SEC66-6HA
8 mps2 2 pRS425-SMY2 SEC66-6HA

Figure 4. Effect of SESA network on translation of IPT1, OPI9 and SEC66 mRNAs. Total cell extracts from yeast strains expressing Pom34-6HA, IPT1-6HA, OPI9-6HA and SEC66-6HA were analyzed by immunoblotting using anti-HA antibodies. Anti Tub2 antibodies were used as loading control.

ases. The main criteria for this is the correct duplication of the centrosome. Current status of the SESA project, makes an unexpected connection between centrosome duplication and translational control. It is important to uncover SESA system in detail not only for closely related areas such as cancer, aneuploidy, protein synthesis, but also for similar systems in higher eukaryotes such as Maskin-CPEB (X. laevis) $[14,15]$, 4E-T-CPEB (X. laevis) [16], Cup-Bruno (Drosophila) [17-20]. In this work we showed that Pom34 mRNA is the only target of the SESA network. This highly sensitive selection to choose and inhibit one single mRNA among more than 6000 mRNAs is quite remarkable and its mechanism remains to be uncovered.

\section{ACKNOWLEDGEMENTS}

This work was supported by TUBITAK. Project number: $114 Z 949$.

\section{References}

1. S.L. Jaspersen, M. Winey, The budding yeast spindle pole body: structure, duplication, and function, Annu. Rev. Cell Dev. Biol., 20 (2004) 1-28.

2. M.A. D'Angelo, M.W. Hetzer, The role of the nuclear envelope in cellular organization, Cell. Mol. Life Sci., 63 (2006) 316-32.
3. M. Winey, L. Goetsch, P. Baum, B. Byers, MPS1 and MPS2: novel yeast genes defining distinct steps of spindle pole body duplication, J. Cell Biol., 114 (1991) 745-54.

4. M.C. Munoz-Centeno, S. McBratney, A. Monterrosa, B. Byers, C. Mann, M. Winey, Saccharomyces cerevisiae MPS2 encodes a membrane protein localized at the spindle pole body and the nuclear envelope, Mol. Biol. Cell, 10 (1999) 2393-406.

5. B. Sezen, M. Seedorf, E. Schiebel, The SESA network links duplication of the yeast centrosome with the protein translation machinery, Genes Dev., 23 (2009) 1559-70.

6. H.J. Chial, M.P. Rout, T.H. Giddings, M. Winey, Saccharomyces cerevisiae $\mathrm{Ndc1p}$ is a shared component of nuclear pore complexes and spindle pole bodies, J. Cell Biol., 143 (1998) 1789-1800.

7. C.K. Lau, T.H.J. Giddings, M. Winey, A novel allele of Saccharomyces cerevisiae NDC1 reveals a potential role for the spindle pole body component $\mathrm{Ndc1p}$ in nuclear pore assembly, Eukaryot. Cell, 3 (2004) 44758.

8. A.S. Madrid, J. Mancuso, W.Z. Cande, K. Weis, The role of the integral membrane nucleoporins Ndc1p and Pom152p in nuclear pore complex assembly and function, J. Cell Biol., 173 (2006) 361-71.

9. J. Mansfeld, S. Guttinger, L.A. Hawryluk-Gara, N. Pante, M. Mall, V. Galy, U. Haselmann, P. Muhlhausser, R.W. Wozniak, I.W. Mattaj, U. Kutay, W. Antonin, The conserved transmembrane nucleoporin NDC1 is required for nuclear pore complex assembly in vertebrate cells, Mol. Cell, 22 (2006) 93-103.

10. E. Onischenko, L.H. Stanton, A.S. Madrid, T. Kieselbach, $\mathrm{K}$. Weis, Role of the $\mathrm{Ndc1}$ interaction network in yeast nuclear pore complex assembly and maintenance, J. Cell Biol., 185 (2009) 475-91. 
11. P. Ross-Macdonald, P.S. Coelho, T. Roemer, S. Agarwal, A. Kumar, R. Jansen, K.H. Cheung, A. Sheehan, D. Symoniatis, L. Umansky, M. Heidtman, F.K. Nelson, H. Iwasaki, K. Hager, M. Gerstein, P. Miller, G.S. Roeder, M. Snyder, Large-scale analysis of the yeast genome by transposon tagging and gene disruption, Nature, 402 (1999) 413-18.

12. C. Janke, M.M. Magiera, N. Rathfelder, C. Taxis, S. Reber, H. Maekawa, A. Moreno-Borchart, G. Doenges, E. Schwob, E. Schiebel, M. Knop, A versatile toolbox for PCR-based tagging of yeast genes: new fluorescent proteins, more markers and promoter substitution cassettes, Yeast, 21 (2004) 947-62.

13. S.S. Katta, J. Chen, J.M. Gardner, J.M. Friederichs, S.E. Smith, M. Gogol, J.R. Unruh, B.D. Slaughter, S.L. Jaspersen, Sec66-Dependent Regulation of Yeast Spindle-Pole Body Duplication Through Pom152, Genetics, 201 (2015) 1479-95.

14. 14. B. Stebbins-Boaz, Q. Cao, C.H. de Moor, R. Mendez, J.D. Richter, Maskin is a CPEB-associated factor that transiently interacts with elF-4E, Mol. Cell, 4 (1999) 1017-27.
15. N. Minshall, M.H. Reiter, D. Weil, N. Standart, CPEB interacts with an ovary-specific elF4E and 4E-T in early Xenopus oocytes, J. Biol. Chem., 282 (2007) 37389-401.

16. N. Standart, N. Minshall, Translational control in early development: CPEB, P-bodies and germinal granules, Biochem. Soc. Trans., 36 (2008) 671-6.

17. A. Nakamura, K. Sato, K. Hanyu-Nakamura, Drosophila cup is an elF4E binding protein that associates with Bruno and regulates oskar mRNA translation in oogenesis, Dev. Cell, 6 (2004) 69-78.

18. M. Chekulaeva, M.W. Hentze, A. Ephrussi, Bruno acts as a dual repressor of oskar translation, promoting mRNA oligomerization and formation of silencing particles, Cell, 124 (2006) 521-33.

19. J.D. Richter, N. Sonenberg, Regulation of capdependent translation by elF4E inhibitory proteins, Nature, 433 (2005) 477-80.

20. N. Sonenberg, A.G. Hinnebusch, Regulation of translation initiation in eukaryotes: mechanisms and biological targets, Cell, 136 (2009) 731-45. 
